\title{
Understanding the Labour Market Participation of Skilled Immigrant Women in Switzerland: The Interplay of Class, Ethnicity, and Gender
}

\author{
Yvonne Riaño • Nadia Baghdadi
}

Published online: 28 December 2007

(C) Springer Science + Business Media B.V. 2007

\begin{abstract}
Switzerland has recently adopted immigration policies that give preference to skilled migrants, the assumption being that migrants with higher education will integrate easily. Our study of 57 skilled immigrant women from Latin America, the Middle East and Southeastern Europe shows that this assumption is largely unjustified. Most of the women cannot use their social and cultural capital to establish themselves in the upper segments of the labour market. A third are not integrated in the labour market and a quarter occupy positions below their skill-level. A further third work at their skill-level but only irregularly. The differentiated participation of these immigrants in the labour market is well explained by analysing the interplay of class, ethnicity and gender.
\end{abstract}

Resumé La politique actuelle d'immigration suisse met son accent sur les migrants qualifiés puisqu'il est présumé qu'ils pourront plus facilement s'intégrer. Notre étude de 56 femmes qualifiées provenant d'Amérique Latine, du Moyen Orient et d'Europe du Sud-Est montre que cette supposition est largement injustifiée. La majorité des femmes ne réussit pas à utiliser leur capital social et culturel pour obtenir des postes exigeant des qualifications. Un tiers n'a pas de travail, un quart occupe des postes au dessous de leurs qualifications et un autre tiers travaille à leur niveau de qualification mais irrégulièrement. Les différences d'insertion dans le marché du travail sont expliquées a partir d'un modèle qui intègre le rôle de classe, d'ethnicité et de genre.

Keywords Skilled immigrants - Labour-market participation · Class · Ethnicity · Gender · Latin Americans · Southeastern Europeans · Middle-Easterners

Mots clés Migrants qualifiés · insertion dans le marché du travail · classe · ethnicité genre

\footnotetext{
Y. Riaño $\cdot$ N. Baghdadi $(\bowtie)$

Department of Geography, University of Bern, Bern, Switzerland

e-mail: baghdadi@giub.unibe.ch

Y. Riaño

e-mail: riano@giub.unibe.ch
} 


\section{Introduction}

The international transfer of knowledge is a prominent feature of today's globalized world. One of the important routes of contemporary knowledge transfer is via migration, particularly through skilled immigrants. The numbers of skilled immigrants are significantly rising, both globally and in Switzerland. Whereas in 1990 only $22.5 \%$ of economically active foreigners in Switzerland were highly skilled, this percentage had increased by the year 2000 to $62 \%$ for recently arrived foreigners $^{1}$ (Pecoraro 2005). Indeed, the new emphasis of immigration policies in Switzerland and other countries in Europe is on acquiring skilled labour to bolster local human resources. The underlying assumption behind attracting skilled migrants is that their knowledge will flow easily into the local economy and that precisely because they are better educated, they will integrate rapidly. There has been scarcely any research in Switzerland on the topic, but preliminary results show that this assumption is largely unjustified. Many skilled immigrants, particularly those from countries outside the European Union, encounter significant difficulties when they try to transfer their educational resources across international boundaries and achieve a professional integration equivalent to their skills (Riaño 2003; Pecoraro 2005). Studies carried out in countries that have promoted skilled immigration for a long time (such as Canada, Australia, New Zealand, and the UK) have shown that skilled immigrants belonging to visible minorities face undervaluing of their credentials and work experience, which results in underemployment and deskilling (Pratt 1999; Li 2001; Iredale 2005; Henderson et al. 2001; Raghuram and Montiel 2003).

Migration to Switzerland has become increasingly feminized in the past decade, particularly in the case of immigrants from countries outside the EU. For example, whereas in 1980 only $48 \%$ of all Latin American immigrants were women, by the year 2005 the percentage had increased to $65 \%$. In the case of Asian immigrants, the percentage of women increased from 46\% in 1980 to 55\% in 2005 (Swiss Federal Statistics 2006). At the same time, in recent years there has been an increase in the educational level of women migrating to Switzerland. Some $40 \%$ non-EU working women have tertiary education whereas this rate is only $18 \%$ among their Swiss counterparts (Swiss Federal Statistics 2006). Despite their growing quantitative and qualitative significance, skilled female immigrants have received scant attention by Swiss researchers.

The aim of this article is to address these research gaps by examining the characteristics of the labour market participation of 57 skilled immigrant women from countries outside the EU, including Latin America, the Middle East and Southeastern Europe, and with contrasting religious backgrounds (Christian/Muslim). ${ }^{2}$ The article

\footnotetext{
${ }^{1}$ The term foreigner (living in Switzerland either temporarily or long term but not having Swiss citizenship), rather than immigrant (foreign-born) is used in Swiss legislation and statistics. This results from a citizenship law that is based on the principle of descent rather than on place of birth. Owing to such law and to restrictive naturalization practices, Switzerland has the second highest percentage of foreigners in OECD countries (22\%). Over half of the 1.7 million 'foreigners' living in Switzerland in 2005 were either born and raised in the country or had lived there for more than 15 years (Swiss Federal Statistics 2006).

${ }^{2}$ This article draws on a larger study, the "Social Integration and Exclusion of Immigrant Women in Switzerland," carried out under the Swiss National Research Programme (NRP 51) on "Social Integration and Social Exclusion." For details see http://www.giub.unibe.ch/sg/immigrantwomen.
} 
is broken down into six parts. The first reviews the literature on skilled migration and the second introduces the integrative approach of class, ethnicity, and gender. The third section presents the case study and the methodological approach of interpretative biography and participatory research. The fourth part describes the educational qualifications and labour market participation of the study participants. The fifth section presents two selected biographies for an empirically based discussion of how structural factors of class, ethnicity, and gender shape access to the labour market. The sixth part looks at immigrant women's reactions to structural barriers and the strategies they develop to confront the challenges of labour market participation. Finally, the conclusions summarize the results and put them in a wider context.

\section{Reviewing the Literature on Skilled Migration}

A review of the literature on skilled migration shows that our understanding of the phenomenon remains limited for the following four reasons.

1. There has been a tendency in the literature and in migration policies to imagine skilled migration as a predominantly male phenomenon and to ignore skilled migrant women. Indeed, there are few studies on skilled migrant women (Kofman 2000) although the numbers of migrant women are high and increasing, particularly in Europe. By the year 2000, 52.4\% of international migrants living in Europe were women (Zlotnik 2003). Besides, skilled immigrant women have remained largely invisible in the literature on female migration as researchers have been mostly preoccupied with women who enter the lesser-skilled sectors, in particular domestic labour (Salazar Parreñas 2001) and with topics such as the trafficking of women (Le Breton Baumgartner 1999) and "the feminisation of survival" (Sassen 2002).

2. The role of gender has not been sufficiently highlighted in studies of labour market participation. Studies in Canada, Germany and the UK demonstrate that immigrant women are doing worse than immigrant men in the labour market and that they are particularly affected by deskilling processes (Kofman 2000; Salaff and Greve 2003, Statistics Canada 2003, Gutiérrez-Rodriguez 1999). Gendered structural barriers seem to play a central role in women's ability to obtain a job. For example, women's child-raising responsibilities, combined with gender discrimination by employers and ethnic prejudice, constrain their access to fulltime skilled positions. Immigration regulations also play a role as many immigrant women enter countries of destination with a family-class visa under which they are not expected to find work and contribute to the economy of the new country. Unfortunately, the extent to which gender dynamics play a role in the marginal position that migrant women occupy in the labour market remains insufficiently understood (Preston 2003).

3. Most of the literature on skilled migration has dealt only with labour migrants, largely ignoring skilled migrants who are present in family and refugee streams. Recent studies in the UK and Canada suggest that many skilled immigrants, particularly women, do not cross international boundaries as labour migrants but in the context of family migration, marriage, or seeking asylum (Kofman 2000; 
Ruddick 2004). Researchers argue that neglect of the economic significance of family migration has concealed the skill level that many women entering as family migrants bring with them and discounted their potential contribution to the labour market (Kofman and Raghuram 2006). The necessity to address family-related migration in studies of skilled migration is illustrated by the Swiss case. Approximately $43 \%$ of Switzerland's immigrants officially migrate for reasons of marriage or family reunification, whereas only $26 \%$ of the immigrants enter for reasons of employment (Swiss Federal Statistics 2006). ${ }^{3}$ In the Swiss and European context of increasingly restrictive regulations for labour migration, especially for migrants from countries outside the EU, study, marriage, and family reunification remain the main migration channels.

4. The literature on skilled migrants has largely focused on occupations in the fields of science and technology, giving less attention to welfare sectors (i.e., education, health and social services), which are strongly feminized (Kofman and Raghuram 2006), and to the social and behavioural sciences. This article addresses the gaps in the literature by focusing on migrant women, paying attention to issues of gender, and examines the variety of forms of entry and occupations of skilled migrant women.

\section{Understanding the Position of Skilled Immigrants in the Labour Market}

How is it best to understand the dynamics of immigrants' positioning in the labour market? Some authors have argued for the necessity of assessing the role of ethnic perceptions in influencing the value attributed to an immigrant's personal and educational resources (Bauder 2003; Fibbi et al. 2004) whereas others have insisted on the importance of gendered norms in producing unequal resource allocation (Kofman 2000). Feminist researchers are arguing that a comprehensive understanding of social positioning and inequality requires an integrated approach that examines the interplay of several markers of difference such as class, ethnicity, and gender (Anthias 2001; Knapp 2005). There is ongoing debate about whether to think of those variables as having a cumulative or an intersectional effect (Walgenbach 2006). It seems, however, that more effort has been invested in conceptualizing than in providing an empirical basis for discussion. At the same time, studies of skilled migration have paid little attention to the interplay of class, ethnicity and gender although it seems a particularly relevant approach for understanding the position of immigrants in the labour market. In this approach the symbolic value given to an individual's resources is central to understanding the dynamics of resource allocation. Only the symbolic value attributed to a specific resource makes it a socially valued resource. The allocation of hierarchies of value, the devaluing of certain resources, and the resulting unequal access to socially valued resources may very much depend on class, gender and ethnicity (Anthias). Thus in the context of this article we ask the following questions: When and how do

\footnotetext{
${ }^{3}$ One of the reasons that the ratio of family-related immigration to economic immigration is so high is that the number of employment immigrants is strictly limited by the Swiss government, whereas family migration is not so tightly controlled. 
class, gender, and ethnicity play a role in shaping the position of skilled immigrant women in the labour market? What kind of role do they play? In what cases and under what circumstances may one category work not to immigrant women's disadvantage but to their advantage?

The following section outlines a conceptual framework for the practical examination of the above questions, We start with the question of the societal levels from which class, ethnicity, and gender should be examined. According to Bourdieu's (1977) "theory of practice", the actions of individuals are both constrained by, but at the same time constitutive of, a deeper structure. This implies that gaining a thorough understanding of the labour market participation of skilled immigrant women necessitates addressing both the macro-level of structure and the micro-level of human agency. Macro-level factors such as social discourses and policies on immigrants may be decisive in aiding or impeding social integration. Human agency factors such as the associative actions of immigrants may have great potential in sustaining the access of immigrant women to social resources. The literature on skilled migration has rarely (Erel 2003; Riaño 2003) given attention to the agency of immigrants. This article will thus addresses both structure and agency.

Above we argue that access to socially valued resources may depend on class, ethnicity, and gender, but how is each of these categories to be thought about? Although a separation between the three categories is only possible a priori, we attempt to grasp the conceptual meaning of each in turn. In the case of class, social stratification approaches conceptualize it as follows. "Class classification starts off from the allocation of individuals, sorting their competencies on the basis of criteria of marketability of skills, economic function, property and knowledges" (Anthias 2001, p. 378). Bourdieu (1986) has argued that class position depends not only on economic, but also on social and cultural capital. He conceives social capital as a durable network of more or less institutionalized relationships of mutual acquaintance, influence, and support. It is a personal asset that provides tangible advantages to those individuals, families, or groups that are better connected. Cultural capital refers to three types of assets that a person may possess: embodied in the individual as long-lasting dispositions of the mind and body (attitudes, behaviour, gender, and ethnicity); objectified in cultural goods (dress, pictures, books, instruments); and institutionalized as academic credentials and diplomas. Social and cultural capital can be converted into economic capital and thus become constitutive of class positioning. Although Bourdieu did not apply this theory to immigrant populations, it is more than suitable for studying the extent to which skilled immigrants can use their social and cultural capital to gain access to positions in the upper segments of the labour market. The fact that the value given to each form of capital is not universal, but context-specific (Kelly and Lusis 2006), is of particular importance here. The valuation of an individual's capital depends on the social norms and value systems of the specific socio-spatial context in which the individual is situated at a specific point in time. Thus the second set of questions addressed in this article are: To what extent are skilled immigrant women from Latin America, the Middle East, and Southeastern Europe able to use their "imported" social and cultural capital to gain access to positions in the upper segments of the Swiss labour market? What are women's strategies for enhancing or recreating the value of their social and cultural capital? 
The concept of ethnicity, simply defined, refers to national, cultural, religious, linguistic, or other attributes that are perceived as characteristic of distinct groups. In the European context, the term ethnicity is used rather than race, and it is understood in territorial terms, thus making a distinction between local and foreign groups. Ethnicity can be studied from the perspective of self-identification (i.e., groups and individuals seeing themselves as having a collective identity because of common ethnic categories such as race, origin, language, religion, and history) or from the perspective of dominant groups categorizing minority groups (i.e., the demarcation of boundaries between $u s$ and those who are different). Examples are the "Othering" discourses about immigrants that have framed Swiss immigration policies since World War II such as "Überfremdung" (the idea that foreign "overpopulation" threatens Swiss identity) and "cultural proximity to the Swiss" (Riaño and WastlWalter 2006). Such conceptualizations have produced a stratified system of civil rights that initially distinguished between Swiss and non-Swiss populations and now distinguishes between EU and non-EU nationals. Thus national origin determines the rights of immigrants: EU citizens have preferential rights of immigration, settlement, and employment over non-EU citizens. ${ }^{4}$ Thus, the third set of questions raised here are: What is the role of ethnic representations as embedded in migration policies and in the minds of institutional actors and employers in Switzerland in shaping immigrant women's access to the skilled labour market? Under what circumstances can ethnicity be an asset or a disadvantage? What role does ethnicity play in the strategies that immigrant women develop?

Gender has been understood in much of the feminist literature as a social category that refers to the various roles that society, groups, and individuals expect of men and women. Social constructions of gender have material effects that shape the everyday lives of women and men. So, for example, ideas about feminine identity ("femininity") and masculine identity ("masculinity") ascribe specific characteristics, roles, and spaces to men and women. Simply said, representations of home, domesticity, and part-time paid employment are usually infused with ideas about femininity, identifying women rather than men as caregivers, domestic workers, and consumers. In contrast, ideas about full-time employment and social participation outside the home are often shaped by ideas about masculinity, reflected in notions of a male breadwinner and the suitability of men rather than women for certain spheres of work and participation in public life. Such ideas have structured many social practices and institutional arrangements in Switzerland, resulting in gender inequalities in the labour market and in other public spheres of society. Although more women than ever before work outside the home, they remain disproportionately responsible for child care and domestic work and are more likely to be employed on a part-time basis and to earn lower wages than men (Strub et al. 2005). ${ }^{5}$ Thus in this

\footnotetext{
${ }^{4}$ The civil rights of EU citizens have recently improved owing to the 2001 bilateral agreement between Switzerland and the European Union on the free movement of individuals. Besides immigration priority, EU nationals enjoy the same living and working rights as the Swiss except for voting. Immigration for non-EU citizens remains limited to skilled personnel, and their settlement and employment rights are weaker than those of EU citizens.

5 The "Gender Gap Index", a survey of 58 countries worldwide published by the World Economic Forum in 2005, put Switzerland in 34th position, far behind most Western European countries and behind lowerincome countries such as Costa Rica, Colombia, and Uruguay.
} 
article we ask a fourth set of questions: What is the significance of social constructions of femininity and masculinity in shaping the characteristics of the labour market participation of skilled immigrant women? What is the role of gender in structuring immigrant women's agency?

\section{Case Study and Methodology}

This article focuses on a case study of 57 immigrant women (who were born abroad and migrated to Switzerland as adults) originating from countries outside the EU in Latin America (Mexico, Nicaragua, the Dominican Republic, Colombia, Venezuela, Peru, Bolivia, Brazil, Argentina), the Middle East (Turkey, Iran, Iraq, Lebanon, Egypt, Tunisia, Libya, Morocco) and Southeastern Europe (Kosovo, Bosnia, Montenegro), and with contrasting religious backgrounds (Christian/Muslim). There has been little research in Switzerland on women from countries outside the EU despite their increasing numbers, reduced civil rights, and the social prejudice that many face owing to their country of origin and/or religion. This lack of attention reflects past migration trends. Whereas until the 1980s most immigrants to Switzerland originated from member countries of the EU, immigrants currently increasingly hail from more distant locations, including the former Yugoslavia, Turkey, and other countries outside the EU (Swiss Federal Statistics 2006). The groups chosen for this study are good examples of current migration trends in Switzerland. The numbers of Latin American women have more than tripled in the past decade; they are increasingly well qualified (55\% have either completed high school, vocational training or university education); and $50 \%$ of those over 20 have migrated because of marriage to a Swiss national (Swiss Federal Statistics 2000, 2006). The number of Muslim migrants, particularly from the Middle East and Southeastern Europe, has doubled in the past decade, and the percentage of women has increased from $36 \%$ in 1990 to $45 \%$ in 2000 . Women with Muslim backgrounds are also increasingly well qualified. In terms of numbers, Islam has become the third most important religion in Switzerland after Catholicism and Protestantism (Swiss Federal Statistics 2000).

The strategy for choosing our research partners followed the principle of theoretical sampling (Glaser 1992), whose aim is not accurate statistical representation, but gaining a thorough understanding of the studied phenomenon by detailed analysis of relevant case studies. Choosing relevant case studies consisted of choosing those individuals who represented the range of situations among firstgeneration skilled migrant women such as entry status (marriage, family reunion, study, work and asylum-seeking); age (28-60 years); time of residence (3-30 years); residence status (yearly permit, permanent residence, Swiss citizenship); and marital status and family situation (single, married, divorced, with and without children). We found our research partners through personal contacts, leaflet advertising, the "snowball" principle, and through collaboration with immigrant women's organizations that provided further contacts with skilled immigrant women.

At the time of the interviews, study participants were on average 40 years old, had lived in Switzerland for a total of 11 years, and were residents of Zurich, Bern, and Aargau, the three most populated German-speaking cantons of Switzerland. ${ }^{6}$ Table 1

\footnotetext{
${ }^{6}$ Interviews for this study were carried out in Bern in 2004 and in Zurich and Aargau in 2005.
} 
Table 1 Entry status and family situation of study participants

\begin{tabular}{|c|c|c|c|c|}
\hline \multicolumn{2}{|l|}{ Regions of origin } & \multirow{2}{*}{$\begin{array}{l}\text { Latin America } \\
(31)\end{array}$} & \multirow{2}{*}{$\begin{array}{l}\text { Middle East/ } \\
\text { Southeastern Europe } \\
(26)\end{array}$} & \multirow{2}{*}{$\begin{array}{l}\text { Tota } \\
(57)\end{array}$} \\
\hline Total women & & & & \\
\hline \multirow[t]{5}{*}{ Entry status } & Marriage & 22 & 8 & 30 \\
\hline & Refugee & 3 & 11 & 14 \\
\hline & Study & 4 & 2 & 6 \\
\hline & Family reunification & 1 & 3 & 4 \\
\hline & Work & 1 & 2 & 3 \\
\hline \multirow[t]{3}{*}{ Residence status } & Swiss citizenship & 18 & 11 & 29 \\
\hline & Yearly B-permit/F, N & 10 & 8 & 18 \\
\hline & Permanent residence $(\mathrm{C})$ & 3 & 7 & 10 \\
\hline \multirow[t]{3}{*}{ Marital status } & Married & 26 & 17 & 43 \\
\hline & Divorced & 4 & 5 & 9 \\
\hline & Single & 1 & 4 & 5 \\
\hline \multirow[t]{2}{*}{ Family status } & Children & 22 & 22 & 44 \\
\hline & No children & 9 & 4 & 13 \\
\hline
\end{tabular}

Source: MINGA workshops and biographical interviews (Riaño and Baghdadi).

shows significant regional differences among study participants regarding their entry status. Whereas most of the Latin American women entered Switzerland for marriage purposes (mostly with a Swiss citizen), most of the women entering from the Middle East left their countries because of war or political tensions (e.g., Kurdish women fleeing political persecution in Turkey or Iranian women fleeing Islamic fundamentalism). Both patterns are representative of general trends in Switzerland for both groups (Swiss Federal Statistics 2000; Heiniger 2002). The number of women entering the country to work is insignificant, which reflects the fact that the number of labour immigrants from non-EU countries is strictly limited by the Swiss government, whereas family migration is not so tightly controlled. ${ }^{7}$ Most of the women have Swiss citizenship (although the percentage is higher in the case of Latin Americans owing to their higher number of marriages to Swiss citizens) but a third only have yearly permits $(\mathrm{B}, \mathrm{F}, \mathrm{N})$. The large majority of study participants are married and have children.

The research questions in the second section above were examined using the method of "interpretative biography", which "involves the studied use and collection of personal life-documents, stories, accounts and narratives which describe turningpoint moments in individuals' lives" (Denzin 1989, p. 13). We believe that this is a powerful tool for gaining temporal and contextual understanding of the combined role that factors of class, ethnicity, and gender may play in shaping an individual's position in the labour market. Our collection of life stories ${ }^{8}$ was conducted in the framework of participatory research. Our specific approach combined the theoretical premises of educación popular (Freire 1970), postcolonial theory, and feminist

\footnotetext{
${ }^{7}$ Examples of the rare cases of women entering with a work visa are, first, an Argentine woman who was able to enter Switzerland to work because although she grew up in Argentina, her parents were of Swiss nationality, and second, a Bosnian woman who came in the early 1970s as a guest worker at a time of labour shortages in Switzerland.

${ }^{8}$ Life stories span the periods of women growing up, studying and working in their countries of origin through to their decision to migrate and their subsequent experiences of socioeconomic integration in Switzerland.
} 
Table 2 Educational qualifications of study participants at the time of migration to Switzerland

\begin{tabular}{|c|c|c|c|c|c|}
\hline \multicolumn{3}{|c|}{ Areas of geographical origin } & \multirow[t]{2}{*}{ Latin America } & \multirow[t]{2}{*}{$\begin{array}{l}\text { Middle East/ } \\
\text { Southeastern Europe }\end{array}$} & \multirow[t]{2}{*}{ Tota } \\
\hline \multicolumn{3}{|c|}{ Level of skills and study fields at time of migration } & & & \\
\hline \multirow[t]{11}{*}{$\begin{array}{l}\text { Highly } \\
\text { skilled }\end{array}$} & $\begin{array}{l}\text { Fields of } \\
\text { study }^{\mathrm{a}}\end{array}$ & $\begin{array}{l}\text { Commerce and business } \\
\text { administration }\end{array}$ & 7 & 6 & 13 \\
\hline & & $\begin{array}{l}\text { Social and behavioural } \\
\text { sciences }\end{array}$ & 8 & 1 & 9 \\
\hline & & Mass communication & 4 & - & 4 \\
\hline & & Law & 3 & 1 & 4 \\
\hline & & $\begin{array}{l}\text { Education science and teacher } \\
\text { training }\end{array}$ & 2 & 2 & 4 \\
\hline & & Humanities & 1 & 1 & 2 \\
\hline & & $\begin{array}{l}\text { Medical science and } \\
\text { health-related }\end{array}$ & 1 & 1 & 2 \\
\hline & & Fine arts and architecture & 3 & 1 & 4 \\
\hline & & Computer science & 1 & 1 & 2 \\
\hline & & Engineering & & 1 & 1 \\
\hline & & Agriculture & 1 & - & 1 \\
\hline Skilled & \multirow{2}{*}{\multicolumn{2}{|c|}{$\begin{array}{l}\text { High school (later further education in } \\
\text { Switzerland) }\end{array}$}} & - & 11 & $11<$ \\
\hline Total & & & 31 & 26 & 57 \\
\hline
\end{tabular}

Source: MINGA workshops and biographical interviews (Riaño and Baghdadi).

a According to UNESCO/OECD's "Eurostat Questionnaire on Statistics of Education at the Third Level"

theory. The general aim was to include the analytical voice of migrant women in the research process and to establish research partnerships between academics and those outside academia. For this purpose we designed a specific type of participatory workshop by the name of MINGA. ${ }^{9}$ In this method both academics and nonacademics jointly produce knowledge. It consists of an interactive process whereby a group of migrant women meets with the researchers; each woman narrates her own migration history and thereafter the group analyses each individual story. Thus women expand their knowledge by participating in the analysis of their own migration histories and those of the others. The information provided by the workshops was complemented by individual interviews. These consisted of a more detailed narration where each woman had the opportunity to recall her past and to reflect on such experiences.

\section{Educational Qualifications and Labour Market Participation of Study Participants}

Recent research has tended to draw a distinction between skilled immigrants who have completed at least secondary education, and highly skilled immigrants who have a university degree or equivalent (OECD 2002). In this study we include both skilled and highly skilled immigrant women. Table 2 shows the educational qualifications of the women included in this study, that is, their institutionalized cultural capital, at the time of their migration to Switzerland. Regional differences

\footnotetext{
${ }^{9}$ Minga is a Quechua word that means "coming together for the betterment of the community"
} 
Table 3 Characteristics of labour market participation of study participants

\begin{tabular}{|c|c|c|c|c|}
\hline \multicolumn{2}{|l|}{ Area of geographical origin } & \multirow{2}{*}{$\begin{array}{l}\text { Latin } \\
\text { America }\end{array}$} & \multirow{2}{*}{$\begin{array}{l}\text { Middle East/ } \\
\text { Southeastern Europe }\end{array}$} & \multirow[t]{2}{*}{ Total } \\
\hline Type of labour market partici & pation & & & \\
\hline \multirow[t]{2}{*}{$\begin{array}{l}\text { (a) Not in the labour market } \\
(30 \%)\end{array}$} & $\begin{array}{l}\text { Not economically active } \\
\text { (housewives/students) }\end{array}$ & 5 & 5 & 10 \\
\hline & Unemployed & 4 & 3 & 7 \\
\hline \multirow{2}{*}{$\begin{array}{l}\text { (b) Employment below skills } \\
(25 \%)\end{array}$} & Short-term employment & 3 & 1 & 4 \\
\hline & Long-term employment & 7 & 3 & 10 \\
\hline \multirow{2}{*}{$\begin{array}{l}\text { (c) Employment according to } \\
\text { skills }(45 \%)\end{array}$} & Short-term employment & 9 & 7 & 16 \\
\hline & Long-term employment (18\%) & 3 & 7 & 10 \\
\hline \multicolumn{2}{|c|}{ Total } & 31 & 26 & 57 \\
\hline
\end{tabular}

Source: MINGA workshops and biographical interviews (Riaño and Baghdadi).

can be observed again: whereas Latin American women arrive after the completion of their tertiary education (which they obtained in their countries of origin or abroad $^{10}$ ), only about two thirds of the women from the Middle East and Southeastern Europe had completed a similar level of education. Women from the latter region tend to arrive at a younger age and thus $40 \%$ of them carry out their tertiary studies in Switzerland. The two most prevalent fields of study among the highly skilled study participants are commercial and business administration and the social sciences, which together make up nearly $50 \%$ of the total. Professions such as law, fine arts, and architecture, education science and teacher training are second in numerical frequency followed by humanities, medical science, and computer science. Engineering professions are rare. Besides being highly skilled at the time of arrival in Switzerland, $88 \%$ of the Latin American women had worked as skilled professionals either in their countries of origin or elsewhere. This percentage is much lower $(30 \%)$ for women from the Middle East and Southeastern Europe because many more arrive at a younger age. All the women considered in this study speak German (the official language of the Cantons where they live) fluently, and besides their mother tongues they are able to speak an additional two to three languages.

We turn now to assessing the labour market participation of our research partners at the time of their interviews in terms of the three most typical types of participation: (a) not in the labour market $(30 \%)$, (b) employed below skill level (25\%), and (c) employed according to skill level (45\%). As women's employment is in many cases intermittent and characterized by a lack of long-term prospects, a further differentiation of short-term and long-term employment has been introduced for types (b) and (c). From the results presented in Table 3, it can be concluded that the majority of study participants $(82 \%)$ cannot use their social and cultural capital to obtain stable positions in the upper segments of the labour market. A third of the study participants are not integrated in the labour market at all, and a quarter occupy positions for which they are overqualified. A further third work at their skill level, but they are in a precarious situation because their employment is characterized by

${ }^{10}$ Twenty-six of the Latin American women studied in their countries of origin and a further five obtained their degrees at university institutions in the UK, Russia, US, Argentina, and Germany. 
Table 4 Examples of economic occupations of study participants

\begin{tabular}{lcll}
\hline Participation in the labour market & Professional training & Present occupation \\
\hline (a) Not in the labour market & Not economically & Physician (Peru) & Housewife \\
& active & Lawyer (Libya) & \\
& Unemployed & Electrical engineer (Kosovo) & Unemployed \\
& & Systems engineer (Mexico) & \\
(b) Employment below skills & Short-term & Primary school teacher & Supermarket cashier \\
& employment & (Lebanon) & \\
& & Agronomist (Colombia) & Fruit stand seller \\
& Long-term & Lawyer (Venezuela) & Factory worker \\
& employment & Economist (Kosovo) & Cleaning lady \\
(c) Employment according to & Short-term & Architect (Turkey) & Freelance artist \\
& employment & Political scientist (Peru/USA) & Freelance consultant \\
& Long-term & Business administrator & Bank manager \\
& employment & (Mexico) & University lecturer \\
\hline
\end{tabular}

Source: MINGA workshops and biographical interviews (Riaño and Baghdadi).

discontinuity and instability (short-term employment). ${ }^{11}$ Thus only a minority (18\%) are able to occupy positions in the upper segments of the labour market at a level that corresponds to their skills and in employment with long-term prospects. The results of this case study are comparable to those of the 2004 European labour survey: $19.8 \%$ of non-EU immigrant women working in Switzerland are in jobs for which they are overqualified (in contrast to $13.8 \%$ for EU-women and $7.6 \%$ for Swiss women) (Dumont and Liebig 2005).

An examination of the differences in labour market participation among the study participants shows that the percentage of Latin American women who are employed in positions that correspond to their skills and have long-term prospects is more than half that of women from the Middle East and Southeastern Europe. The variety of reasons for this are discussed in the next section, but here we highlight the role of the Swiss context, as a collective form of social norms and value systems in valuating the institutional cultural capital of immigrant women. Latin American women had high qualifications at their time of migration, but they obtained their university degrees outside Switzerland, whereas a significant number of women from the Middle East and Southeastern Europe carried out their tertiary education in Switzerland. Thus the place where an individual earns her or his degree seems to be a decisive factor in successful professional integration. Being able to transfer their institutional cultural capital across borders is not the only difficulty that women participating in this study face: they must also deal with the associated problems of deskilling, loss of confidence, and loss of autonomy. As can be seen in Table 4, which presents examples of the actual occupations of the women in this study, many have occupations well below their skills and original socio-professional status. Thus for these women migration means not an improvement but rather a loss of class status.

\footnotetext{
${ }^{11}$ These are the cases of women who prefer to create their own employment (e.g., freelance work as occasional translators, report writers or video producers) rather than being unemployed or of women who obtain occasional employment as replacement teachers or short-term project employees.
} 


\section{The Shaping of Skilled Immigrant Women's Position in the Swiss Labour Market}

Here we address the question of how to explain the differences in the labour market participation of immigrant women as presented above. In order to better grasp the workings of class, gender, and ethnicity in shaping the labour market position of immigrant women, we start by presenting two contrasting biographies. The first, Yolanda's, ${ }^{12}$ illustrates the case of the many women who end up in precarious situations, and the second, Zehra's, exemplifies the rare case of those who are able to reach the upper segments of the labour market.

\section{Yolanda's biography}

Yolanda grew up in the Carribean. At the age of 20 she moved to a socialist country in Eastern Europe where a government fellowship was available for her university studies. Six years later her strong motivation earned her a university degree in Psychology and Philology. She met her future husband, a Swiss, during her studies and later on they moved to Switzerland. Yolanda was very motivated to practice her profession, an aim she felt confident of achieving because of her young age (27), good qualifications, international experience, Swiss husband, and Swiss nationality. ${ }^{13}$ Initially, her husband's friends helped her to get a job at a home for the elderly, first as a nursing assistant and later as social activity organizer. Her elderly patients questioned her skills because she was dark-skinned. Disillusioned by the experiences of the first years, by the jobs' lack of professional perspective and feeling the "biological clock" pressure to have children, she decided to quit her elder-care job. After having two children it became clear that childcare was going to be her responsibility: her husband was committed to a full-time job and the daycares' policy was not to give priority to women with highly-paid husbands. Yolanda got by by teaching languages at a night school. In time her Swiss friends helped her to get occasional replacement jobs as a language teacher at a high school. Despite her proven teaching skills, the school authorities told her that they could not offer her a regular position because she did not have the Swiss Höheres Lehramt degree, the prerequisite for teaching at a high school. Yolanda also applied for several jobs as a psychologist, but was told by her prospective employers that they could not accept her foreign degree and that she needed the Swiss degree known as Berufsbegleitende Psychotherapeutische Ausbildung. She consulted a vocational counsellor who informed her that obtaining such a degree would require three to four years and cost a significant amount. Yolanda's concern about how to finance such studies and combine them with her family responsibilities was interpreted by the counsellor as her "not being psychologically ready" to study. The counsellor advised her to think that "family work was also a psychological task" and that she was, "after all, not unemployed." Yolanda is currently 45 years old, has lost her skills as a psychologist and finds herself in an economically unstable and low-paid position in the labour market.

\section{Zehra's biography}

Zehra was a member of the Kurdish opposition in Turkey. She came to Switzerland at the age of 22 as an asylum-seeker together with her husband and twin sons. The Swiss government granted them political asylum and they were able to rebuild their lives. Studying was Zehra's most important goal. Owing to fellowships from the Cantonal government and to part-time jobs, Zehra was able to pursue studies in anthropology. When she divorced her husband and became a single mother, it took her longer to finish her studies, but at the same time, she was able to place her sons at a daycare because single mothers had priority. After finishing her studies she got a job at an NGO working in the field of intercultural activities. Her ethnic background, combined with her Swiss studies, had a positive effect on her employment. She was employed because of her knowledge of several cultures and languages (German, Kurdish, Turkish, English) and two religions (Muslim, Christian). At a later point her ethnicity and her gender seem to have played a negative role when she applied for a leading position at the same organization: "I cannot say that

\footnotetext{
12 The women's names have been changed to ensure anonimity.

${ }^{13}$ Until 1991 foreign women automatically acquired Swiss citizenship with the conclusion of marriage with a Swiss citizen (whereas the foreign husband could only become Swiss by following the usual naturalisation procedure). Since 1992 both foreign women and foreign men who marry a Swiss citizen need to live in Switzerland for five years and be married for at least three years before applying for Swiss citizenship.
} 
being a foreigner played the only role; I would say as a woman you have difficulties, one way or another. There were two applicants at the end. He was a man and I was a woman. He was a Swiss and I was a foreigner. And I think religion also played a role, although that was obviously never mentioned." She is currently 44 years old and now holds a full-time permanent position as lecturer of intercultural pedagogy at the University of Applied Sciences in Zurich. Her origin, combined with her Swiss degree, worked to her advantage in obtaining the job. Her success also resides in the fact that she is a very strong and persevering person with clear strategies with which to accomplish her goals.

The above histories reveal two highly motivated women with very different outcomes in terms of labour market participation. Yolanda's initial social and cultural capital (tertiary education, Swiss nationality and a Swiss-born husband) seemed more favourable than Zehra's (no tertiary education, refugee, single mother) in achieving successful labour market participation. How can the unexpected outcome be explained? As we explain below, factors of class, gender, and ethnicity combined to shape different outcomes. For a start, Yolanda was not able to use her class status to get access to the upper segments of the labour market because her social and cultural capital was devalued in the Swiss context. Her foreign credentials were not recognized; the value of her Swiss nationality was dampened by negative perceptions of her racial features; her husband's circle of friends was valuable in providing jobs, but those jobs confined her to either unskilled or unstable occupations. Not having her skills recognized put Yolanda in the same situation as Zehra's, that of having to start from scratch to complete her tertiary education. Factors of class, ethnicity, and gender explain why Zehra succeeded whereas Yolanda did not. First of all, having children in Switzerland is a serious impediment for immigrant women's aim of studying and working. The prevailing value that "good mothers stay at home" has generated a lack of institutional facilities for childcare. The idea that children need to go home for lunch has produced school schedules that force one of the parents to stay at home, usually the mother. Because immigrant women lack family support since their families typically live abroad, they are dependent on external childcare. However, the daycares' policy of giving priority to women "who need to work" excludes married women with well-salaried husbands. Thus being a single parent and having a low socioeconomic status worked to Zehra's advantage in solving the problem of external childcare support.

Second, the financing of university studies was a main issue for both Zehra and Yolanda, as it is for all the women who participated in this study. Access to public financial resources is shaped by class, ethnicity, and gender. For example, Zehra was able to obtain fellowships from the Cantonal government because of her refugee status and low-income situation. Yolanda, in contrast, had no access to government fellowships because of her marriage-migrant status and husband's good salary. Swiss institutional actors see that it is essential to support the economic integration of refugees, whereas the same is not the case for immigrant spouses. An example is the VIntA integration policy, ${ }^{14}$ which has as its priority "to support immigrant women in acquiring the German language so that they can help their children integrate into Swiss society." The homemaking role of foreign spouses, rather than their labour market participation, is thus implicit in such policies. Besides, vocational counsellors

14 "VintA" is the official decree that regulates the principles and objectives of foreigners' integration in Swiss society as well as the type and characteristics of federal subsidies used for that purpose. 
act as transmitters of such vision, as Yolanda's example above shows. Further, integration policies such as VIntA are aimed at poorly educated women and thus do not support the educational advancement of skilled migrant women. An example is the lack of advanced language programmes for migrant women despite their great importance. The women in our study reported that language perfection is given more importance by many employers for skilled positions than are professional experience and social competence. Furthermore, the peculiar language situation of Germanspeaking Cantons, in which the spoken language (Swiss-German dialect) is different from the written language (High German), makes it difficult for immigrants to compete with Swiss-born individuals in the job market.

If public funds are not available for the tertiary education of immigrant women like Yolanda, to what extent, then, are family resources available for their education? Yolanda's example shows that factors of inequality between husband and wife as determined by gender and ethnicity are a main obstacle. She recounts that she and her husband gave higher priority to investing the family's resources in his educational advancement, because he, unlike her, as a Swiss-born person with Swiss education, had a higher potential of earning a good salary to support the family. Thus while Yolanda was learning German and raising children, he completed two postgraduate courses and a doctorate, which led him to a good position in the Swiss labour market. Being a refugee, a single parent, and having a low socioeconomic status worked to Zehra's advantage in her objective of completing her studies, whereas Yolanda's situation of being a skilled immigrant in a binational marriage with a Swiss worked to her disadvantage.

Zehra's example shows that ethnic origin can be an added value for certain jobs such as in the field of interculturality, especially in combination with a Swiss degree. Ethnicity, however, can also play a negative role in the labour market, especially in combination with gender. Being a foreign woman of Muslim background hindered Zehra's chances for a leading position. All study participants who wear the Muslim headscarf reported discrimination experiences. Rasema, for example, a trained salesperson from Bosnia, reports that she had many difficulties in finding a job after she decided to wear a headscarf, despite her good qualifications, German proficiency, extensive social network, and high commitment. She remained unemployed for many years until she found employment in a company owned by a Tunisian Muslim. The effects of ethnic prejudice toward women from Latin America, the Middle East, and Southeastern Europe and gender-biased ideas about technical professions are best illustrated by the examples of Besma, an electrical engineer from Kosovo; Üenay, an architect from Turkey; Natalia, a construction draftsperson from Colombia; Yasi, a systems engineer from Mexico; and Mona, an agricultural engineer from Colombia, none of whom ever succeeded in finding a job in the professions for which they were trained. At the time of the interviews, four of these women were unemployed and a fifth worked as a fruit stand seller.

Ethnic representations can also act as a barrier for the realization of the institutional cultural capital of immigrants from countries outside the EU, as the example of the credentialing of foreign degrees shows. Whereas in recent years academic institutions and employers have increasingly recognized credentials from EU countries, there is much reluctance toward accepting those from countries outside the EU. This situation is further complicated by the fact that Switzerland as a federal nation has no uniform 
credentialing system. Each Canton making up the Confederation has its own educational and accreditation system. Because of this lack of a unified accreditation system, decisions by institutional representatives are necessarily subjective and often inconsistent. For example, Joana, a Brazilian psychologist, applied to the University of Fribourg for recognition of her degree and was told that she needed to redo two years of university education to obtain the equivalent Swiss degree. She also applied to the University of Bern and was told that she needed to repeat her entire tertiary education. She demanded information from the Swiss Psychologists' Association and was informed that her studies in Brazil were equivalent to those of psychology students in Switzerland.

Ethnic representations, combined with traditional ideas of gender roles as embedded in Swiss immigration policies, also play a main role in constraining the labour market integration of skilled immigrant women. For example, visas for foreign spouses from countries outside the EU are designed to allow them "to remain with their spouses," but not to stimulate economic activity (the great majority of foreign spouses are women). Such visas contain no explicit work permit (unless it can be proved that there is no Swiss or EU citizen who can take the job), must be renewed every year, and are contingent on women remaining with their spouses. Spouses married to Swiss or EU citizens receive a permanent residence visa, which gives them the unrestricted right to work after five years, whereas spouses married to citizens from countries outside the EU receive this right only after 10 years. As many Swiss employers require a permanent visa for skilled positions, it is in practice difficult for immigrant women holding a yearly visa to obtain a skilled job in the first five to 10 years of residence. After such a long period, immigrant women inevitably lose their skills and the prospects of obtaining a stable job in their professions of origin are drastically reduced.

\section{The Response of Skilled Migrant Women to the Challenge of Labour Market Participation}

A common denominator in the narratives of our research partners is the great value that they give to their professional development. Women's careers have been given greater weight in recent decades in many Latin American, Southeast European, and Middle Eastern societies. Many of our research partners recount that they were raised with the notion that it is very important for women to study and work in order to gain economic independence. How do they cope with traditional ideas about gender roles in Swiss society and the challenge of labour market participation? What strategies do women develop to recreate their social and cultural capital and thus improve their access to the labour market? What roles do class, gender, and ethnicity play in structuring such strategies? Table 5 shows the variety of strategies that women in this study develop in various realms of society and with the aim conscious or unconscious - of attaining social, economic, and personal gains. Women may use one or several strategies at a time, deploying them in varied ways over the years depending on past experiences.

Reskilling is a strategy chosen by many of the participants to rebuild their social and cultural capital, especially after several years of homemaking activities or of working in low-paid and/or unstable employment. As explained above, a high level 
Table 5 Women's strategies and responses to the challenge of labour market participation

\begin{tabular}{|c|c|c|c|}
\hline Realm of action & Strategy & Means & Gains \\
\hline Educational & Re-skill & $\begin{array}{l}\text { Improve German proficiency } \\
\text { Redo tertiary education } \\
\text { Carry out postgraduate studies }\end{array}$ & $\begin{array}{l}\text { Rebuild capital } \\
\text { Wider social } \\
\text { participation }\end{array}$ \\
\hline Labour market & $\begin{array}{l}\text { Work below skills } \\
\text { Create own employment }\end{array}$ & $\begin{array}{l}\text { Take any available job } \\
\text { Set up own business }\end{array}$ & Social recognition \\
\hline & Do volunteer work & $\begin{array}{l}\text { Unpaid work in social } \\
\text { organisations }\end{array}$ & Self-esteem \\
\hline Family & $\begin{array}{l}\text { Family planning and gender } \\
\text { arrangements }\end{array}$ & $\begin{array}{l}\text { Postpone, limit number, no } \\
\text { children } \\
\text { Share child-care tasks with } \\
\text { partner } \\
\text { Separate from partner }\end{array}$ & $\begin{array}{l}\text { Time for work and/or } \\
\text { study }\end{array}$ \\
\hline Personal & $\begin{array}{l}\text { Withdraw from labour market } \\
\text { Find an escape to the situation }\end{array}$ & $\begin{array}{l}\text { Assume domestic role } \\
\text { Return to the country of origin }\end{array}$ & $\begin{array}{l}\text { Motherhood } \\
\text { Personal stability }\end{array}$ \\
\hline
\end{tabular}

Source: MINGA workshops and biographical interviews (Riaño and Baghdadi).

of German proficiency is required for skilled jobs in Switzerland. Thus many women take advanced German classes and others learn the Swiss-German dialect in order to enhance their employment chances. Many realize that they are never going to get a skilled job unless they study in Switzerland and thus decide either to complete tertiary studies, repeat their entire university studies, or do postgraduate work. For example, most of the women in this study who reached their desired professional integration have used such strategies. Others are currently in school, such as Mürside, a graduate English teacher from Turkey who is now studying social work; Alba, a lawyer from Colombia who is repeating her law studies; Hana, a Libyan lawyer who is doing a doctorate in international law; Mona, a Colombian agronomist who is doing a master's degree in ecology; and Juliana, a Peruvian sociologist doing a master's in intercultural communication. Three of these women report that participating in this study's MINGA workshops gave them the encouragement to go ahead with these strategies. Studying requires significant effort, but the women have been resourceful in finding solutions to the problems of time and money. Hana and Mona, for example, brought their mothers from Libya and Colombia to assist them with childcare tasks. Antonia, an anthropologist from Mexico, used the compensation money that she had received as a result of a car accident to finance her postgraduate studies in gender management.

Because many women cannot get a job that corresponds to their qualifications (and/or is in their original fields of study), one of the most common reactions is to take any job available, even if it is below their qualifications. This strategy is often not successful, as over the years women become trapped in a vicious circle and cannot move to more skilled positions. Class plays an important role in choosing this kind of strategy. Some women have no choice because they need to generate an income to support their ill husbands, others need to complement their husband's low income (mostly non-Swiss), and still others need to send money to support their families abroad. Gender also plays a role: many women wish to exercise their professions, but at the same time feel the pressure that "good mothers do not work." 
Working part-time thus becomes a compromise solution. This often entails taking a job below their qualifications because most skilled jobs require full-time commitment.

Other women become tired of their domestic role and/or of their failed access to the labour market. Their response is to create their own employment. Examples of women who use this strategy are Gülay, a Turkish computer specialist who opened a travel agency specializing in travel to and from Turkey; Gloria (Venezuela), Lucia (Peru), Uenay (Turkey), Jana (Peru), and Clara (Peru) who work as freelance journalists, artists, translators, or video producers; and Hamyde, an Islamic theologian from Turkey, who works as a freelance consultant for inter-cultural dialogue. It is interesting to note that many of these women use their ethnic backgrounds (language and culture knowledge) as marketable attributes that allow them access into the labour market, although the economic rewards are not always high.

Carrying out volunteer activities in organizations such as parents' groups, homecountry associations, intercultural schools, music groups, immigrant associations, and organizations for intercultural dialogue is an option chosen by the large majority of the women in our study. Involvement in such organizations offers many advantages to the women: using their professional abilities, expanding their spaces of social participation, struggling for immigrant women's rights, and giving more meaning to their lives. The experience gained in these activities allows some to rebuild their social and cultural capital (networks and professional experience) and results in some cases in paid job opportunities, often according to their skill level. Gender and ethnicity play an important role in this kind of strategy. Being a woman and having first-hand knowledge of several cultures can be an added value for jobs in the field of social care and intercultural dialogue. Several of the women who do volunteer work had already worked in their countries of origin as activists or volunteers in organizations struggling for the rights of women, youth, and minority groups, for example, Antonia (Mexico), Teresinha (Brazil), Azucena (Bolivia), Alba (Colombia), and Cemyle (Turkey).

Some of the women participating in this study realize the importance of taking action in the realm of family planning and gender arrangements if they are to advance professionally. Postponing having children, limiting their number, sharing childcare responsibilities with their partners, or deciding to have no children at all have been decisive factors in their success stories. Such strategies have been mostly used by the younger, more recently arrived women, but also at times by older women whose husbands value the professional advancement of their wives, or by women who have renegotiated gender arrangements with their husbands. Some of the women in this study report that participating in the MINGA workshops reinforced their awareness of the necessity to use that particular strategy. For other women, divorcing their husbands became a means of professional advancement. Not only did they feel freer from the need to conform to gender-specific social norms, but also the loss in socioeconomic status associated with their divorces pushed them to invest much more time and energy in their careers.

Women who became frustrated by the lack of value given to their foreign work experience and the difficulties they experienced in trying to combine a career and a family chose to withdraw from the labour market and concentrate on their domestic roles. Although they become economically dependent on their husbands, the personal and social reward of motherhood becomes a substitute. Class plays an important role here. Many of these women are in a privileged economic position as they are married 
to Swiss-born husbands who earn good salaries (not all women in that situation, however, choose to withdraw from the labour market). This strategy is not entirely satisfactory for many as they remain internally torn, miss their profession, and worry about their future professional prospects. A further option chosen by a small minority of our research partners is to escape the difficult situation of labour market participation by deciding to return to their countries of origin. Because they feel overwhelmed by the situation, finding an escape to it is the only way for them to maintain personal stability.

\section{Conclusions}

This article examines the labour market participation of 57 skilled women from Latin America, the Middle East, and Southeastern Europe, who are immigrants in Switzerland. The study builds on a feminist approach in which the interplay of various markers of difference such as class, ethnicity and gender (Anthias 2001; Knapp 2005) are assessed in order to understand social positioning. Using Bourdieu's (1977) postulate that social and cultural resources can be converted into economic resources and thereby become constitutive of class positioning, we investigated the extent to which skilled immigrant women can use their imported social and cultural capital to establish themselves in the upper segments of the Swiss labour market. The results show that only a small minority of the women in this study have been able to secure employment that corresponds to their skill level and that has long-term prospects. This is remarkable, because most of the women had good educational qualifications and professional experience prior to migration, and all of them mastered the German language. More than half the women in this study cannot maximize their skills in the Swiss labour market because they are either not sufficiently integrated or because they have only found work below their skill level. Nearly a third work in positions suited to their skills, but their employment is precarious because it is intermittent and short-term. Thus for the majority of women in this study, migration means deskilling, loss of confidence, and loss of autonomy. We view this as a missed oppurtunity for "brain gain" for Swiss society.

The nature of the participation of our research partners in the labour market can be explained by the interplay of their class, ethnicity and gender. The social and cultural capital of immigrant women is devalued in the Swiss context. Their premigration social networks are of little value in the Swiss context, and the newly acquired networks confine them to unskilled or unstable occupations. Those who bring educational qualifications and professional experience find that these resources are not valued in Switzerland. Further, the women in this study faced a variety of difficulties in acquiring Swiss qualifications and skilled employment, depending on their entry status, marriage and family situation, and husbands' income and nationality. For example, women who immigrated as spouses of well-salaried Swiss citizens and then had children found fewer opportunities for further education and work: childcare facilities in Switzerland are designated for women who must work; study fellowships are open only to low-income individuals; the financial resources of binational families are more often invested in the education of the Swiss husband 
rather than that of the immigrant wife; and marriage migrants, unlike refugees, are not encouraged by immigration policies to play an economic role in society. Thus, paradoxically, more opportunities were available to women who entered as refugees, became single mothers, and had low incomes. Regardless of these differences due to entry status and family situation, all the women in our study reported a further, common set of hurdles to their participation in the labour market: many Swiss employers discriminate against women from non-EU countries because of their origin, race, or religion; other Swiss employers prefer men (and especially Swiss men) rather than women (and especially non-EU women) for technical occupations and for leadership positions; skilled migrant women cannot benefit from state integration programmes, because these focus only on low-skilled immigrants and promote women's childcaring role. In contrast, ethnicity and gender played positive roles in the case of jobs where knowledge of several cultures and languages and being a woman were considered assets (e.g., occupations in the field of intercultural communication and social care). Thus the possibilities for our study participants to use their social and cultural resources to access the upper segments of the Swiss labour market depend on context-specific social norms and value systems regarding class, ethnicity, and gender.

These conclusions have four important implications for further studies of labourmarket participation and inequality. First, linking Bourdieu's $(1977,1986)$ concepts of social and cultural capital with feminist ideas about the interplay of class, ethnicity, and gender proved a fruitful approach for understanding the positions of skilled immigrant women in the Swiss labour market. Second, the analogy of an intersection used in some of the feminist literature does not seem to be a useful way to view how class, ethnicity, and gender simultaneously shape an immigrant's position in society. Such an analogy conveys the impression that the combination of three negatives automatically and permanently results in social exclusion. This study shows that at any given time in an individual's working lifetime, class, ethnicity, and gender may in fact take on positive or negative roles, depending on the socio-spatial context and on the type of occupation that the immigrant is striving to obtain. Moreover, the constellation of advantages and disadvantages posed by an individual's class, ethnicity, and gender may change with time in response to evolving personal variables (e.g., educational advancement, job experience, language skills, and family situation) or external constraints (e.g., state policies, job opportunities). Third, studies of labour market participation need to give attention to both structure and agency. Women in this study were not passive to the unfavourable conditions that they faced in the Swiss labour market, but rather mobilized many personal resources to help them gain access to or improve their participation in the labour market. Finally, assessing the combined roles of class, ethnicity, and gender in shaping women's position in the labour market represents a methodological challenge. The methods of interpretative biography and participatory workshops used in this study proved powerful tools for gaining thorough temporal and contextual understanding. The MINGA workshops designed for this study provided a particularly suitable framework for bringing out the variety of women's experiences and for expanding the knowledge of both immigrant women and researchers regarding the difficulties of labour market participation. 
Acknowledgements The authors gratefully acknowledge the support of this research by grant 405114069125 from the Swiss National Science Foundation, National Research Programme 51 on Social Integration and Social Exclusion. This paper was written with support of SNF-grant PIOI1-115231. We thank two anonymous reviewers for their helpful comments on earlier versions of this article.

\section{References}

Anthias, F. (2001). The material and the symbolic in theorizing social stratification: issues of gender, ethnicity and class. British Journal of Sociology, 52(3), 367-390.

Bauder, H. (2003). Brain abuse, or the devaluation of immigrant labour in Canada. Antipode, 35, 699-717. Bourdieu, P. (1977). Outline of a theory of practice. Cambridge: Cambridge University Press.

Bourdieu, P. (1986). The forms of capital. In J. G. Richardson (Ed.), Handbook of theory and research for the sociology of education (pp. 241-258). New York: Greenwood Press.

Denzin, N. (1989). Interpretative biography. Qualitative research methods series: 17. Sage Publications.

Dumont, J.-C., \& Liebig, T. (2005). Labour market integration of immigrant women: Overview and recent trends. In OECD \& European Commission Seminar, Migrant women and the labour market: Diversity and challenges, Room Document N. 3, OECD. Brussels.

Erel, U. (2003). Citizenship practices and skilled migrant women. In M. Morokvasic, U. Erel, K. Shinozaki, (Eds.), Crossing borders and shifting boundaries. Vol 1: Gender on the move. Opladen: VS Verlag.

Fibbi, R., Kaya, B., Piguet, E. (2004). Le passeport ou le diplôme? Etudes des discriminations à l'embauche des jeunes issus de la migration. Neuchâtel: SFM.

Freire, P. (1970). Pedagogy of the oppressed. New York: Continuum.

Glaser, B. (1992). Emergence versus forcing: Basics of grounded theory analysis. Mill Valley, CA: Sociology Press.

Gutiérrez-Rodríguez, E. (1999). Intellektuelle Migrantinnen - Subjektivität im Zeitalter der Globalisierung. Opladen: Leske \& Budrich.

Heiniger, M. (2002). Muslime und Musliminnen in der Schweiz - ein statistischer Überblick. In R. Pahud de Mortanges, E. Tanner (Eds.), Muslime und Schweizerische Rechtsordnung. Fribourg: Universitätsverlag.

Henderson, A., Trlin, A. D., \& Watts, N. (2001). Squandered skills? The employment problems of skilled Chinese immigrants in New Zealand. In R. Starrs (Ed.) Asian nationalisms in an age of globalization (pp. 106-123). Richmond: Curzon Press.

Iredale, R. (2005). Gender, immigration policies and accreditation: Valuing the skills of professional women migrants. Geoforum, 36, 155-166.

Kelly, P., \& Lusis, T. (2006). Migration and the transnational habitus: Evidence from Canada and the Philippines. Environment and Planning A, 38, 831-847.

Knapp, G.-A. (2005). "Intersectionality" - ein neues Paradigma feministischer Theorie? Zur transatlantischen Reise von "Race, Class, Gender.” Feministische Studien, 1, 68-81.

Kofman, E. (2000). The invisibility of skilled female migrants and gender relations in studies of skilled migration in Europe. International Journal of Population Geography, 6(1), 45-59.

Kofman, E., \& Raghuram, P. (2006). Gender and global labour migrations: Incorporating skilled workers. Antipode, 38(2), 282-303.

Le Breton Baumgartner, M. (1999). Illegalisierung und Kriminalisierung der Migrantinnen. "Frauenhandel" im Kontext restriktiver Einwanderungspolitik. Widerspruch, 37, 83-93.

Li, P. S. (2001). The market worth of immigrants' educational credentials. Canadian Public Policy, 27(1), 23-38.

OECD. (2002) International mobility of the highly skilled. Paris: OECD Policy Brief.

Pecoraro, M. (2005). Les migrants hautement qualifiés en Suisse. Forum, 4, 37-39, Neuchatel: SFM.

Pratt, G. (1999). From registered nurse to registered nanny: Discursive geographies of Filipina domestic workers in Vancouver, BC. Economic Geography, 75(3), 215-236.

Preston, V. (2003). Gender, inequality and borders. ACME: An International E-Journal for Critical Geographies, 2(2), 183-187.

Raghuram, P., \& Montiel, D. (2003) Skilled migratory regimes: The case of female medical migrants in the UK. In A. Montanari (Ed.), The new geography of human mobility: Inequality trends (pp. 67-84). Rome: Home of Geography Publication.

Riaño, Y. (2003). Migration of skilled Latin American women to Switzerland and their struggle for integration. In Y. Mutsuo (Ed.), Latin American emigration: Interregional comparison among North America, Europe and Japan. JCAS Symposium Series 19. Osaka: Japan Centre for Area Studies. 
Riaño, Y., \& Wastl-Walter, D. (2006). Immigration policies, state discourses on foreigners and the politics of identity in Switzerland. Environment and Planning A, 38(9), 1693-1713.

Ruddick, E. (2004). Skilled female migrants to Canada. Paper presented at the 9th International Metropolis Conference, Geneva, Switzerland.

Salaff, J., \& Greve, A. (2003). Gendered structural barriers to job attainment for skilled Chinese emigrants in Canada. International Journal of Population Geography, 9, 443-456.

Salazar Parreñas, R. (2001). Servants of globalization: Women, migration and domestic work. Stanford: Stanford University Press.

Sassen, S. (2002). Countergeographies of globalization: The feminization of survival. Paper presented at the conference on "gender budgets, financial markets, financing for development", Heinrich-Boell Foundation, Berlin, Germany.

Statistics Canada. (2003). The Canadian labour market at a glance. Labour statistics division, catalogue no. 71-222-XIE. Ottawa: Statistics Canada.

Strub, S., Hüttner, E., \& Guggisberg, J. (2005). Arbeitsteilung in Paarhaushalten: Aufteilung von bezahlter und unbezahlter Arbeit in der Schweiz. Neuchâtel: Swiss Federal Statistics.

Swiss Federal Statistics. (2000). Swiss Census Statistics 2000. Neuchâtel: Swiss Federal Statistics.

Swiss Federal Statistics. (2006). Foreigners in Switzerland. Neuchâtel: Swiss Federal Statistics.

Walgenbach, K. (2006). Die weiße Frau als Trägerin deutscher Kultur. Koloniale Diskurse über Geschlecht, "Rasse" und Klasse im Kaiserreich. Frankfurt: Campus.

Zlotnik, H. (2003). The global dimensions of female migration. Migration information source. Washington: Migration Policy Institute.

Yvonne Riaño has a PhD degree in Geography from the University of Ottawa (Canada). She currently teaches at the Department of Geography at the University of Bern (Switzerland) and leads a Swiss National Science Foundation research project on the "Social Integration and Exclusion of Immigrant Women in Switzerland". Her migration and gender research encompasses European and Latin American cities. Her current research focuses on skilled migration, migration and citizenship, immigrants' associations and state discourses on immigrants and refugees. Her methodologies are grounded in feminist and postcolonial approaches, emphasizing the use of participatory methods.

Nadia Baghdadi has an MA degree in Islamic and Middle Eastern Studies. She is currently carrying out $\mathrm{PhD}$ research at the Department of Geography at the University of Bern (Switzerland) and at the School of Health and Social Sciences at Middlesex University (United Kingdom). Her PhD thesis is entitled "Crossing, Experiencing and Dealing with Boundaries. Life Paths and Occupational Histories of Skilled Immigrant Women of Muslim Background". Her areas of research interest include Islamic studies, gender and migration, official discourses on women and nation making, postcolonial approaches and participatory methods. 